\title{
Integrated Work Breakdown Structure for Shipbuilding on Department Group Machinery Part Zone Block Engine Room
}

\author{
Wolfgang Busse ${ }^{1}$, M. Badrus Zaman ${ }^{2}$, Pratama Akbar $^{3}$ \\ (Received: 24 September 2020 / Revised: 03 March 2021 / Accepted: 05 March 2021)
}

\begin{abstract}
- in the work breakdown structure for shipbuilding of machinery outfitting is related to machinery, ducting, hvac \& piping, steel work, and insulation. Integrated work breakdown structure is one of the shipbuilding methods involving in management, so that design time is shorter. The ducting, HVAC \& piping is the system based on the contract assignment and drawing approval by classification society. Then, we compare the effect of each Time Estimation. Then, continue with combine product and project structure. Problem start with how do we compare old with new WBS technology, no optimization process, and no working breakdown structure for the outfitting in the engine room. Bar chart, combination of industrial and financial system with design software also program project evaluation and review technique methodology will be used. Results obtained a work breakdown structure for Guidelines. The Aim was for optimization process time. The schedule created compared with the actual schedule that occurs so that we can see there is a difference of time shows that the shipyard applies integration. This also will lead to man-hour optimization. It is concluded that an integrated work breakdown structure can be applied to obtain the shipyard design in a shorter time.
\end{abstract}

Keywords— engine room zone, integrated work breakdown structure, shipbuilding.

\section{INTRODUCTION}

The advancement of shipbuilding technology from year to year is always facing an update in line with the discovery of new ways of development that are definitely optimal in terms of price and time. In addition, the nominal shipbuilding companies from within the country and also outside the country always increase from time to time. The situation increasingly makes a number of ship owners become increasingly choosy on the choice of the ship that they want to make in the shipyard by the way the delivery time must be fast as well as the quality that can be justified.

In 2017 there are approximately 250 shipyards located in Indonesia, 37 percent are located in Java, 26 percent are on Sumatra Island, 25 percent are on Kalimantan Island and 12 percent are in Eastern Indonesia, almost all operating in the middle to lower sphere. Besides that, there is a shipyard around ASEAN that is more active in the field of the latest technology usage related to shipping building facilities, also fierce competition in the shipbuilding industry in the State of Indonesia. Therefore, it needs research and development on the purpose of sustainable development system development efforts in line with the even distribution of advanced technology, especially relation.

PT. PAL is one of the largest shipyards in the country of Indonesia and also a State-Owned Enterprise in addition to three other shipyards, namely PT. Dock and Shipping of Kodja Bahari (DKB), PT. Surabaya Dock

Wolfgang Busse is with Department of Maritime Studies, Hochschule Wismar, Rostock, 18119, Germany. E-mail: wolfgang.busse@hs-wismar.de

M. Badrus Zaman is with Department of Marine Engineering, Institut Teknologi Sepuluh Nopember, Surabaya, 60111, Indonesia, E-mail: druz_zaman@ne.its.ac.id

Pratama Akbar is with Department of Maritime Studies, Hochschule Wismar, Rostock, 18119, Germany. E-mail: rabka.pratama@gmail.com and Shipping (DPS) and PT. Indonesian Ship Industry located in Makassar City. At this time PT. PAL has 4 production division units located in Surabaya. Pay attention to PT. PAL Surabaya consists of the Commerce Division, Warship Division, Submarine Division, and Maintenance Division. Repairs whose location is still close together, the author intends to try to analyze a concept of the latest shipbuilding by combining several system methods in the shipyard during the construction of a ship. In other words, a ship consisting of a number of blocks is made by more than one department by reviewing the nature of each division to be integrated into each block. This concept is known by the term of Work Breakdown Structure.

PT. PAL Indonesia (Persero), which has a core business in the field of shipbuilding, maintenance, ship repair, and ship conversion is a domestic shipyard industry that has international standards and has ISO 9001 standards. Many trials must be encountered by local shipyard companies such as PT. PAL Indonesia (Persero) today, such as the increasingly rapid shipyards that lead to similar types of markets, the limited mastery of technology, and the quality of available human resources have caused PT. PAL to be able to compete in the international market, facilitate bidding and fulfill methods payments are generally available on global orders, because of the lack of long-term capital.

Work breakdown structure is a concept that is attempted to be introduced in the shipbuilding flow that combines several ways that lie in management as well as similar methods so that the development time obtained becomes faster. This concept has been applied to one of the shipyards in Korea, such as Daewoo Shipbuilding \& Marine Engineering (DSME Shipyard), which is a shipyard in the world that introduces shipbuilding methods with the Work Breakdown Structure or WBS process. As with the characteristics of the integrated work breakdown structure. 
The work needed for each large construction project must be subdivided so that it is easily analyzed and managed. Such a distribution scheme is a work breakdown structure.

Traditional shipbuilders employ work subdivisions by the ship's functional system that is natural and suitable for estimating and for the initial design phase. However, system orientation for planning, scheduling, and implementation are unnatural and inappropriate because it leads to poor work coordination and generally produces work packages that are too large for effective material control, working hours and schedules.

The method of shipping several ships and most other artificial artifacts, which are actually produced is by holding or making parts and combining them to make small combinations. Instead, this is combined through several manufacturing levels to produce larger blocks. So, the ideal way to divide ship construction work is to focus on the necessary parts and other combinations, for example, temporary products that grab workers' attention. The scheme for dividing work according to the art of temporary product display is a work breakdown structure.

The need for a product-oriented work breakdown structure that fits the way the ship was built was identified for Indonesian shipbuilders more than a decade ago. At that time there were large applications by several overseas shipbuilders.

For the case, the author took the example in the form of data on a ship that had been made on one of the boat docks that had by PT. PAL Indonesia. Then carried out trial and analysis of data when made using the Integrated Work Breakdown Structure. The output obtained from there is a tangible result of the comparison from the time of the next manufacture will provide a recommendation on the shipyard in the manufacture of a ship that is better in the current time and in the future. So that it will make competitiveness (Cost, Quality, Delivery) to be offered to ship owners.

To build a ship with a low cost, high quality, and short manufacturing time a production system is needed that can produce efficiency in the entire production system. Work Breakdown Structure is a method of shipbuilding that can solve this inefficiency problem because with the Work Breakdown Structure method in the stages of shipbuilding there will be several uses, namely the total time needed can be reduced, work stages become simpler, work-in-process (WIP) down inventory, faster manufacturing lead time, maximum yield satisfaction, better management control, because the feedback is based on manufacturing and accountability that comes from team performance.

Based on the explanation in the previous background, the main problems in this study that must be resolved at the point of the problem in this study are:

1. How do we compare old technology (WBS) without material code with new WBS technology with part numbering full online?

2. There is no optimization process of the shipbuilding process that involves a constraining limit of man-hour, database, and time.
3. There is no working breakdown structure of the supporting concepts for the construction of the ship material number in the engine room block zone workflow.

The purpose of this research is to study the Work Breakdown Structure process as a basis when finding a more precise optimization of shipbuilding methods, so as to be able to offer this advantage to prospective ship owners who plan to own a ship and increase the competitiveness of shipyards.

In the completion of this research, the aim is to provide appropriate advice to the shipyard for efforts to create highly efficient production guidelines to assist production activities in the current and future times and to optimize the shipbuilding process involving costs and a timely manner.

The aims of this research are to design a work breakdown structure (WBS) in the shipbuilding process at PT. PAL Indonesia, carry out the design and development of a Work Breakdown Structure simulation model with a CADMATIC NAPA simulation model, carry out experiments and quality engineering of shipbuilding systems in PT. PAL Indonesia with the Integrated method Work Breakdown Structure.

In detail, the purpose of this study is to answer problems, namely:

1. Design a by planner work breakdown structure plan that is in the process of building the ship

2. Knowing how IWBS can be determined as a reference for optimizing the shipbuilding process

3. Knowing how to optimize the shipbuilding process and time manner

4. Observe the effect of design in the ship production process

5. Knowing the influence of the environment on the shipbuilding process

6. Observe the comparison of old manual WBS technology without code with the new WBS technology with material code

7. Provide recommendations for work breakdown structures that provide optimal results in the shipbuilding process

8. Selection of the main constituent groups in the block zone machinery in the engine room

9. Studying and understanding the supporting system of the shipbuilding process at PT. PAL Indonesia provides quality and effectiveness. 


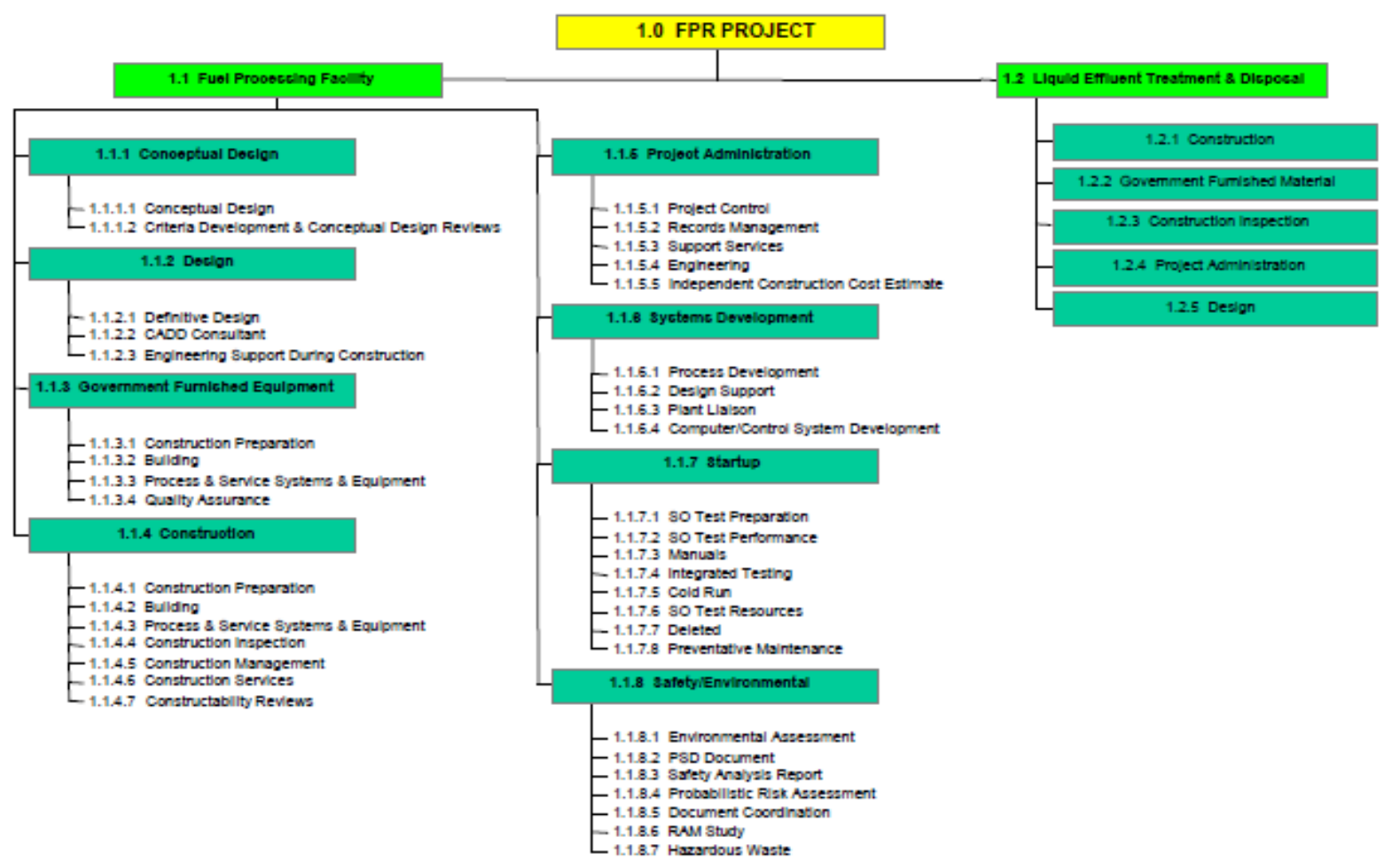

Figure. 1. Project Work Breakdown Structure [1].

WORK BREAKDOWN STRUCTURE DICTIONARY

mคöC IIIE

PROACCI ID COMPANY

PROJECT MANAGER

DAFE

(1000

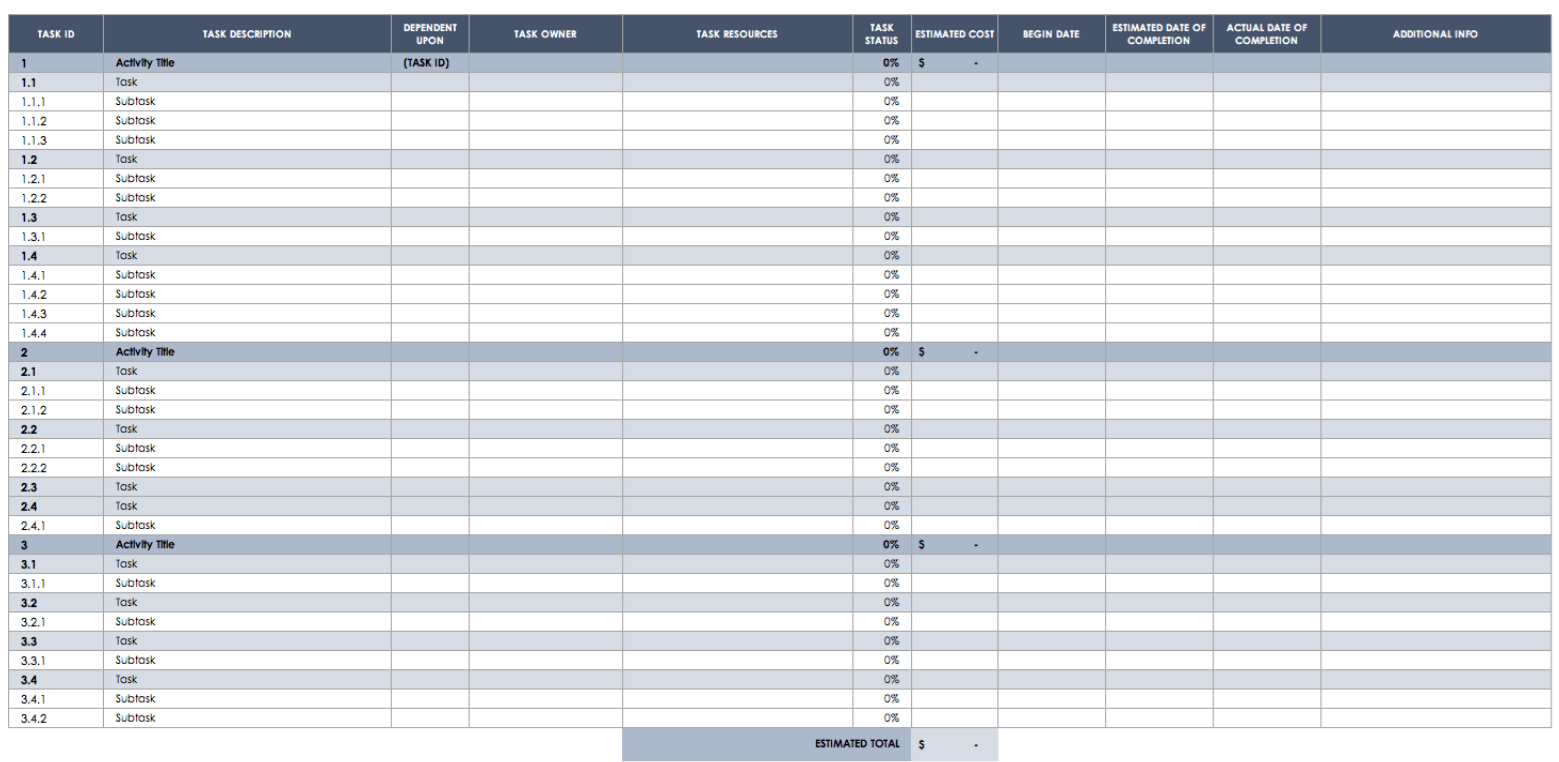

Figure. 2. Work breakdown structure dictionary [2].

The benefits obtained from this research are:

1. Provide an overview of the work breakdown structure needed for the shipbuilding process

2. Determine the needs of the detailed structure of the work that serves the construction of ships in the engine room block zone

3. Understand the design characteristics of the work breakdown structure for ship construction

4. Study on the implementation of detailed design

\section{METHOD}

This chapter describes the process of analyzing information from research sources. This research method is needed as a research framework that aims to make the research systematic, structured, and directed. In this research method, there are 5 five steps as follows:

Methods written in the manuscript include:

1) General

2) Identification of Problems 
3) Design of WBS

4) Determine Master Schedule

5) Determine Design Detail Schedule

6) Analysis Integrated WBS

7) Conclusions and Recommendations

\section{A. General}

1) This Chapter will describe the Systematic steps that will be carried out in this Research. The Methodology is the Basic Framework of the Stages of Completion of the Research. This Research writing Methodology covers all Activities that will be carried out to solve the problem or carry out the Analysis Process of the Research Problem.

2) This Research Methodology, for more details, will be described as follows.

\section{B. Identification of Problems}

1) Identification determines the product that will be produced in the research process. The work carried out to identify the problem of each workload (weight and complexity of the work) raised in this study is to define and explain the statement of the research project as well as strategies for the optimization method of the product structure.

2) This Research starts with identifying and formulating problems regarding the steps to be carried out and also the limits of the problem. This is done to simplify the problem so as to facilitate the work and completion of writing this Research.

\section{Design of WBS}

To design an old method WBS that is conventional WBS, it must look at the environmental conditions where the KCRS PAL TNI-AL 60 is located. This stage will also be explained in designing WBS.

TABLE 1. COMPARISON OF TWO METHODS IN SHIPBUILDING WBS

\begin{tabular}{cc}
\hline Shipbuilding Method & $\begin{array}{c}\text { Duration Time } \\
\text { (Days) }\end{array}$ \\
\hline Without IWBS & 541 \\
With IWBS & 247 \\
\hline
\end{tabular}

\section{Determine Master Schedule}

Determine the Master Schedule. After determining the intended product, the data needed and identification of the characteristics of each bureau then is to create a Master Schedule. In this step determine the target time needed to complete each product produced. The Master Schedule is the basis for making a job details schedule. This process creates value and registers the work (and how the results will be measured) by determining the work of the WBS (Workload and Time of Work for each Job) and also determines the main master schedule that must be prepared by the supporting modules.

\section{E. Determine Design Detail Schedule}

After determining the Master Schedule, the project data document needed and identification of the characteristics of each work plan then is to create a Design Detail Schedule. This step determines the design time needed to continue to create the procurement process. The Design Detail Schedule is the basis for making Material Procured List. This process creates a Drawing List and List of the Estimates Material and the time.

\section{F. Analysis Integrated WBS}

The next process is determining iteration. In this step, a job description, job description, and workload will be needed to reach the goal with the target time specified in the previous stage. At this stage, the synchronization schedule between the bureaus will be carried out in detail and on an ongoing basis to obtain optimal time optimization for the procurement process by the needs of the structure of the project work description of the ship. Where will be evaluated the distribution and determination of work results in tasks that can be managed by determining the order of the design schedule in each part of the work and calculating the total design time to the procurement process.

\section{G. Conclusions and Recommendations}

The conclusion expected in the writing of this research was expected to be able to answer the problem that is the purpose of this research. Suggestions are written based on the results of the discussion as well as available facts. This advice is given to improve this research to make it more perfect. The final step is to create a work package consisting of a list of material estimates, a list of drawings, and detailed man-hours of people working time. From the results of this step, we get WBS. Where the determination for the value of each part is obtained.

\section{RESULTS AND DISCUSSION}

\section{A. Project Control}

To control the ship's steps by analyzing the information method Integration of Work Details Structure that has been obtained from the source carried out in the discussion. The author at this stage of the research remains on the basis of determining the amount of work according to the method of separation of responsibilities carried out by PT. PAL Surabaya Indonesia so that the research steps are carried out regularly, integrated, structured, and detailed. In order to realize the goal, this discussion uses stages with methods such as the following steps:

The author determines the software program that is a means of planning tools or core control, with various considerations as below:

- It has been established as a focused program as a design of new ships by the Central PAL company. 
- Has the most advanced workspace capability among others.

- Has a detailed integrated device capability.

- Located affiliations in the city center of Surabaya, where various of them do not provide such support centers like the others.

\section{B. Determination of the Group Bureau}

Each shipping project specifies some of the structure of the ship's work details and most of the different artifacts are made, which are actually made by forming or forming parts and connecting them so as to make small combinations. Basically, the details of the structure of this work are various among the combined factors that must be monitored as well as being the benchmark of the author through several manufacturing levels to produce the engine room zones which are increasing including the following:

- Time for a shipyard to build block zone engine room +540 days

- The time from the shipyard to build machinery equipment $+17,250$ hours

TABLE 2.

DISTRIBUTION OF HEAVY DUTY MACHINERY FOR SHIP EQUIPMENT 60 METERS [3]

\begin{tabular}{ccc}
\hline No & $\begin{array}{c}\text { Item } \\
\text { Machinery Outfitting }\end{array}$ & $\begin{array}{c}\text { Weight } \\
\text { (ton) }\end{array}$ \\
\hline 1 & Main Engine & 25.23 \\
2 & Propulsion Unit & 7.69 \\
3 & Generator Set & 6.82 \\
4 & Auxiliary Engine & 8.58 \\
5 & Piping \& Valve & 29.89 \\
6 & Found. Of Auxiliary Engine & 2.94 \\
7 & Independent Tank & 12.91 \\
8 & Workshop Equipment & 0.25 \\
\hline
\end{tabular}

\section{Machining Equipment Process Application}

Each machining equipment process application consists of a structure for the ship's work details and most of the different artifacts come from Preliminary, which is basically made from forming parts and connecting each other so that to be small combinations. Basically, the details of the process application of this work come from among the combined factors as well as preliminary of the author through several manufacturing.

1) Preliminary

In detail, the method of calculating the research that I use is to understand how many times the answer to the problem of the example of the ship ends is made, which is similar to the calculation method of PT. PAL with the basis of shipyard people's ability to be the core theme besides workload, effective hours, and a number of workers available.

2) Limits used:

The author only compares and understands the old system supporting the process of manufacturing ship machinery at PT. PAL Indonesia, where the guideline for connecting all production blocks that have been qualified and implemented is effective without fulfilling the factors of the hull construction needs of the company.
3) Assumptions used

Workers Needs

- All workers who participated directly in the design $=175$ people (according to available data).

- Division of labor in each block adjusts to a load of each block zone

- Construction of ranges based on the calculation of labor required on the basis of double block engine rooms which must adjust to the main

schedule in which laying off is carried out 4 months after the contract runs.

- 4 months is defined as 90 days, of which one month has 22 effective days of work $->22 \times 4=$ 88 -> to be 90 days.

$$
90=\frac{94309.69(\mathrm{~kg})}{9 \frac{\mathrm{kg}}{\mathrm{MH}} \times 8 \frac{\text { hours }}{\text { day }} \times \text { manpower }}
$$

Labor on the basis of double bottom engine room = 15 people

- Then, a lot of labor needed for each block is used in such a way that it matches the load of the block with the level of difficulty of the structure so that the number of workers is 175 along with the completion of each block does not require a long time / shorter.

TABLE 3.

COMPARABLE OF THE DIVISION EMPLOYMENT FOR PEOPLE NEEDS [4]

\begin{tabular}{cc}
\hline Weight (ton) & Manpower \\
\hline $11-20$ & 5 \\
$21-30$ & 6 \\
$31-40$ & 7 \\
$41-50$ & 8 \\
\hline
\end{tabular}




$\begin{array}{cc}51-60 & 10 \\ 61-70 & 10 \\ 71-80 & 10 \\ 81-90 & 13 \\ 91-100 & 15 \\ 101-110 & 15 \\ 111-120 & 15 \\ 121-130 & 20 \\ 131-140 & 20 \\ 141-150 & 20 \\ 151-160 & 20 \\ 161-170 & 20 \\ & \end{array}$

Distribution of Hours The person in the table above is quite applicable to zone loads whose final results are used at the installation stage. For example, the engine room zone is divided into three group bureaus (HVAC, Miscellaneous \& Steel Work, Machinery and Machining Arrangements \& Propulsion), because the development stage directly unites the engine room zone, so that the designated person clock is 15 people with a zone load of $94,310 \mathrm{~kg}$.

\section{Conventional WBS Process}

The conventional WBS process is based on huge scope WBS activities that are carried out while the shipbuilding stands on the dock before the ship launch. Only a small portion of the initial equipment is carried out on machinery equipment during the next stage of the assembly block just prior to erection on shipbuilding.

Pipe Pieces, Ventilation Ducts, Foundations, Cable Lines, etc. Made at the shipyard workshop and proceed to the location of the equipment on a large pallet, followed by installation at the stage on schedule. As a result, the complete WBS process then requires extensive work completion.
E. Calculation and Analysis Experiments with Traditional Method

In order to understand the length of time that an end zone is created, therefore there are various iterations that are carried out with the standard method of the manhours calculation.

$$
\text { Duration }=\frac{\text { Weight }}{\left(\frac{k g}{M H}\right) \times E H \times \text { Manpower }}
$$

$M H($ machinery outfitting $)=$ Duration $\times$ Manpower $\times E H$

With:

Duration $=$ time it takes to end the zone (hours/day)

Load = load of a zone $(\mathrm{kg})$

$\mathrm{Kg} / \mathrm{MH}=$ Man Hours ability of shipyard every $\mathrm{kg}$

$\mathrm{EH}=$ efficient hours every day (6 hrs) overtime $(2 \mathrm{hrs})$

Man Power $=$ many direct workers are needed

$\mathrm{M} / \mathrm{H}=$ many people are needed for settlement per zone

After understanding the iterations used, the writer describes the calculations in table format along with various variations that have been understood. Namely many tangible labors, the burden of each bureau, $\mathrm{kg} / \mathrm{JO}$ every shipyard, and People's Hour (JO).

TABLE 4.

CALCULATION OF ENGINE ROOM BLOCK ZONE DURATION TIME

\begin{tabular}{cccccccc}
\hline No. & Block & Weight (ton) & Area & $\begin{array}{c}\text { Total weight } \\
\mathbf{( k g})\end{array}$ & $\begin{array}{c}\text { Manhour } \\
\text { total } \\
\text { (calculation) }\end{array}$ & $\begin{array}{c}\text { Total } \\
\text { manpower }\end{array}$ & $\begin{array}{c}\text { Duration } \\
\text { (day) }\end{array}$ \\
\hline 1 & 20101 & 10,5 & $\begin{array}{c}\text { Double } \\
\text { bottom }\end{array}$ & 10489 & 1049 & 5 & 26 \\
2 & 20102 & 36,5 & $\begin{array}{c}\text { Double } \\
\text { bottom }\end{array}$ & 36516 & 3652 & 7 & 65 \\
3 & 20201 & 24,6 & $1^{\text {st deck }}$ & 24597 & 2460 & 6 & 51 \\
4 & 20202 & 5,0 & $1^{\text {st }}$ deck & 5023 & 502 & 5 & 13 \\
Total & 76,6 & & & 5662 & & \\
\hline
\end{tabular}

The table above has shown that each zone can end at a certain time according to the capabilities of each shipyard. Through the Integrated Work Breakdown Structure method, making is attempted to be able to be done with a total load and a lot of weight simultaneously. Because of this, there are more than one zones created in advance with the zone which has been postponed for how long it takes to have time to do the integration step without loss.

The author plans the method stages of Machinery Outfitting such as:

Zone integration step (Zone Block) with the work division structure in the engine room zone 


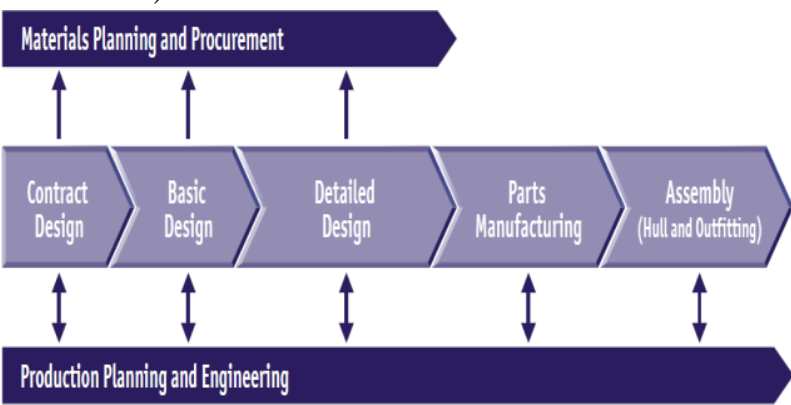

Figure. 3. Process of building ships concept to delivery.

Because of the limited data that the author found, the detailed design schedule was only carried out in the Machine Room. The basis of this schedule is the variation equation used so that the output is compared can the author take responsibility. From this schedule, the author likens the sorting of the design steps into 5 steps, namely the basic stage, the key plan stage, the yard plan stage, the production drawing stage and the final stage \& the procedure test, the test record. The author makes a parable that the basic stage requires $11 \%$ of the work from all the time needed, while the key plan stage requires $14 \%$ of the total duration. For the basis of the Clock the person used is the base of the PAL Ship, which is $10 \mathrm{~kg} / \mathrm{JO}$. From that estimate, the author obtained a detailed design schedule as shown in the following table.

TABLE 5.

SCHEDULE OF 60 METER SHIP DESIGN DETAILS TRADITIONAL METHOD

\begin{tabular}{|c|c|c|c|c|}
\hline \multirow[t]{2}{*}{ Item name } & \multicolumn{2}{|c|}{ Duration } & \multirow[t]{2}{*}{ Start date } & \multirow[t]{2}{*}{ Finish date } \\
\hline & Days & Hours & & \\
\hline SCHEDULE DESIGN PROJECT KCRS 60M & & & & \\
\hline BASIC MO & 57 & 1842 & Fri 23/12/11 & Mon 12/03/12 \\
\hline KEYPLAN & & & Fri 21/10/11 & Mon 14/05/12 \\
\hline KEYPLAN MO & 77 & 2464 & Fri 30/12/11 & Mon 16/04/12 \\
\hline YARD PLAN & & & Wed 28/12/11 & Thu $16 / 08 / 12$ \\
\hline YARD PLAN MO & 147 & 4704 & Wed 28/12/11 & Thu 19/07/12 \\
\hline MATERIAL LIST & 145 & 4640 & Wed 28/12/11 & Tue $17 / 07 / 12$ \\
\hline PRODUCTION DRAWING & & & Thu 29/03/12 & Fri $14 / 09 / 12$ \\
\hline PIPING IN ENGINE ROOM & 27 & 864 & Thu 29/03/12 & Mon 07/05/12 \\
\hline HVAC, MISC \& ST. WORK & 68 & 2176 & Thu 26/04/12 & Tue $31 / 07 / 12$ \\
\hline FINAL \&TP-TR MO & 20 & 640 & Mon 03/10/11 & Tue $04 / 09 / 12$ \\
\hline TP \&TR OF ANCHOR SYS (INCL WINDLASS) & 3 & 96 & Tue 22/05/12 & Fri 25/05/12 \\
\hline TP \&TR OF STEERING GEAR & 3 & 96 & Fri 25/05/12 & Wed 30/05/12 \\
\hline TP \&TR OFGENERATOR ONBOARD & 3 & 96 & Fri $10 / 08 / 12$ & Tue $14 / 08 / 12$ \\
\hline TP \&TR OF MAIN ENGINE MONITORING SYSTEM & 3 & 96 & Tue $05 / 06 / 12$ & Thu $07 / 06 / 12$ \\
\hline TP \&TR OF AIR COND. PLANT \& MECHANICAL VENT. & 3 & 96 & Wed $11 / 07 / 12$ & Tue $17 / 07 / 12$ \\
\hline TP \&TR OF ENGINE TELEGRAP SYSTEM & 3 & 96 & Fri 08/06/12 & Tue $12 / 06 / 12$ \\
\hline TOTAL & 541 & 17952 & & \\
\hline
\end{tabular}

The table explains of 60 Meter Ship Design Details that consist of Basic M.O. duration finish 57 days, Key Plan M.O. which finish 77 days, Yard Plan M.O. \& Material List finish 147 days \& 145 days, Product Dwg includes
Piping in E/R and HVAC, Miscellaneous \& Steel Work Product Dwg. finish 27 days and 68 days \& Final Dwg. \& T.P. T.R. M.O. finishes 20 days.

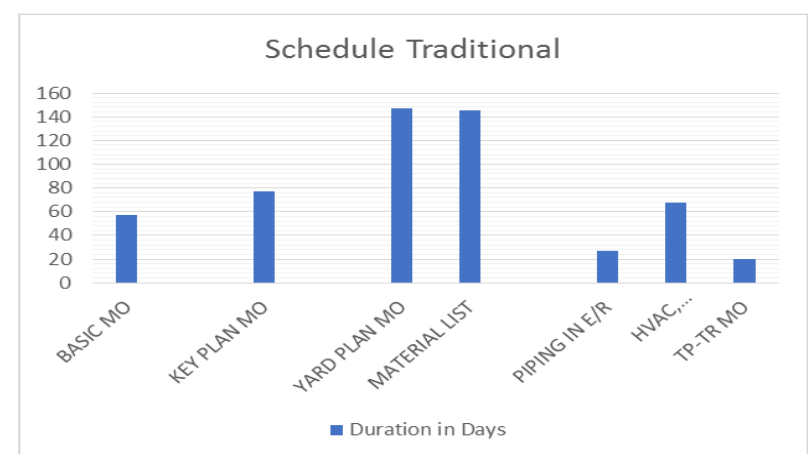

Figure. 4. Bar chart process of shipbuilding a $60 \mathrm{M}$ fast attack craft with a traditional method.

For example, we can see 1 st Deck. In that zone, the basic stage needed for the construction of the zone is 57 days, the key plan stage takes around 77 days, the yard plan stage takes 292 days, the production drawing stage requires 95 days and the procedure test $\&$ test record takes 20 days. So the entire time period needed to build the Machine Room is 541 days (see table).

From the predetermined schedule, the following is the estimated calculation of the $60 \mathrm{M}$ Fast Attack Craft project using traditional methods: 
a. Total Machinery outfitting workforce requirements $=33$ people $/$ day

b. Total usage of $\mathrm{MH}$

$=541 \times 8 \times 33$

= 142.824 Man Hours

c. Cost assumption (IDR 40,000 / Man Hour)

$=142.824 \times$ IDR 40.000

$=$ IDR 5.712.960.000

The length of time needed for the design in the basic stages, key plan, yard plan, production drawings, and procedure tests and this test record takes a number of 541 days or approximately 24 months 13 days (with 22 effective working days each month).

\section{F. Design of the IWBS}

The Project Management Knowledge Body, is a collection of internationally recognized and accepted processes and fields of knowledge as the best practice for the project management profession, defining work breakdown structures as "hierarchical decomposition of the total scope of work that the project team will do to achieve project objectives and produce results.

\section{G. Integrated WBS Approach}

As such, WBS is optimized, based on technical, related, regulatory, and economic parameters. Using a WBS integration approach that requires various changes in the design and technological stages of shipbuilding, such as higher efforts to plan and prepare documentation, as well as better engineering, higher quality assurance with a better level of design standards.

WBS may be as small as one job that is installed on a common supporting component and is also ready to be installed on the panel, on-block, or onboard. Or as a series of equipment, pipelines, floors, electricity, and other systems that are quite complex, all of which are planned on the supporting of the Integrated Work Breakdown Structure.

One major advantage of the integrated WBS approach is that work can be made and assembled with smaller and more flexible procedures located outside the shipyard itself. Such alternative work can be very significant and more efficient than the conventional method.

\section{G. Project Scope}

The project room is the KCR Ship Project stage is a continuation of the construction and planning of the ship with the construction of 3 decks namely deck level 01 (roof), main deck, deck 1st, and battleship planning with 3 deck planning namely deck 1st, main deck and deck level 01 ( roof). The project space includes MO work.

1) MO Projects

\section{Machinery Outfitting}

- Machinery

- Main Engine

- Generator

- Emergency Generator

- Propellers and Shafts

- Auxiliary Machinery

- Air Receiver
- Instrumentation

- $\quad$ Steel Works

- Engine Room Crane System

- $\quad$ Steel Works in Machinery Outfitting

- HVAC on Machinery Outfitting

- $\quad$ Piping

- $\quad$ Soil \& Drain

- FO, LO \& Oily Drain

- $\quad$ LO \& Transfer Service

- $\quad$ Bilge, Ballast \& Fire

- Oily Bilge

- Transfer LO Purifier

- Transfer FO Purifier

- FO Services \& Purifier

- HT, LT \& FW Cooling

- SW Cooling \& SW Sanitation Service

- FW Service

- Compressed Air

- Control Air

- LO Drain

- Exhaust Gas

- Drain, Flushing LO \& Circulation

- Air Ventilation \& Filling

- Fire Protection System (CO2 System)

- $\quad$ Pipe Support (Including All Systems)

- Insulation

- Wall Insulation

- Piping Insulation

- Equipment Insulation

- Thin Plate Insulation

Manufacturing Equipment

Steel Works

- $\quad$ Steel Works in Machinery Outfitting

- $\quad$ Piping

- $\quad$ Piping in Hull Outfitting

- Piping in Machinery Outfitting

- Pipes in Accommodation Outfitting

- HVAC

- Ducting

- Ventilation Head

From the results of data analysis, the Fast Attack Craft $60 \mathrm{M}$ Outfitting Schedule has a duration of completion time of 11.22 months (247 days), the project began on 20 April 2018 and was completed on 28 January 2020.

Figure 4 shows bar chart process of shipbuilding a 60 $\mathrm{m}$ fast attack craft with IWBS. From the predetermined schedule, the following is the estimated calculation of the $60 \mathrm{M}$ Fast Attack Craft project total workforce requirement with Integrated Work Breakdown Structure:

a. Total Machinery outfitting workforce requirements $=35$ people / day

b. Total usage of $\mathrm{MH}$

$=247 \times 8 \times 35$

$=69.160$ Man Hours

c. Cost assumption (IDR 40,000 / Man Hour)

$=69.160 \times$ IDR 40.000 
that it is understood and delegated. Regarding that is the activity of the initial steps of controlling the project.

TABLE 6.

CRITICAL PATH OF KCR $60 \mathrm{M}$

\begin{tabular}{|c|c|c|c|c|}
\hline \multirow{4}{*}{ DWG. NO. } & Task Name & Duration & Start & Finish \\
\hline & SCHEDULE DESIGN PROYEK KCRS $60 \mathrm{M}$ & 463 days & Fri 20/04/18 & Tue $28 / 01 / 20$ \\
\hline & KEY PLAN & 122 days & Thu 31/01/19 & Fri 19/07/19 \\
\hline & KEY PLAN MO & 57 days & Thu 31/01/19 & Fri 19/04/19 \\
\hline \multirow[t]{7}{*}{5110001} & ARRANGEMENT OF ENGINE ROOM / E/R LAYOUT & 15 days & Tue $26 / 03 / 19$ & Mon $15 / 04 / 19$ \\
\hline & YARD PLAN & 239 days & Thu 21/02/19 & Tue $21 / 01 / 20$ \\
\hline & YARD PLAN MO & 188,15 days & Mon 11/03/19 & Thu 28/11/19 \\
\hline & YARD PLAN PIPING \& HV/AC ARR'T & 126,15 days & Wed 05/06/19 & Thu 28/11/19 \\
\hline & PIPING IN HULL IN "3" DECK & 52 days & Mon 17/06/19 & Wed 28/08/19 \\
\hline & MODEL PIPING IN HULL "3" DECK & 22 days & Mon $17 / 06 / 19$ & Wed $17 / 07 / 19$ \\
\hline & BLOCK SS1A/SS2A/SS3A & 30 days & Wed 17/07/19 & Wed 28/08/19 \\
\hline 4116005 & PIPING, SUPPORT, PENETRATION ARR'T IN "3" DECK BLOCK SS1A/SS2A/SS3A & 15 days & Wed 07/08/19 & Wed 28/08/19 \\
\hline \multirow[t]{2}{*}{$4 \mathrm{P} 16005$} & PIPE SKETCHES IN "3" DECK BLOCK SS1A/ SS2A/ SS3A & 15 days & Wed $17 / 07 / 19$ & Wed $07 / 08 / 19$ \\
\hline & MISCELLANEOUS / OTHERS DRAWING & 132,45 days & Mon 22/04/19 & Wed 23/10/19 \\
\hline 5174001 & ARR'T \& DETAIL OF WORKSHOP IN COMP. IV & 10 days & Thu $16 / 05 / 19$ & Wed 29/05/19 \\
\hline 5176002 & ARR'T OF FLOOR \& GRATING IN COMP. III\&V & 10 days & Wed 28/08/19 & Wed $11 / 09 / 19$ \\
\hline 5174010 & ARR'T OF VENTILATION IN GENERATOR ROOM & 5 days & Thu $30 / 05 / 19$ & Wed $05 / 06 / 19$ \\
\hline 4116910 & ARR"T \& DET. VENT. HEAD IN AFTER \& FORE PART & 5 days & Thu 06/06/19 & Wed $12 / 06 / 19$ \\
\hline 4115917 & ARR'T \& DETAIL OF VENT HEAD IN ACCOMMODATION. & 5 days & Thu $13 / 06 / 19$ & Wed $19 / 06 / 19$ \\
\hline \multirow[t]{2}{*}{5171004} & ARR'T. VENTILATION HEAD IN E/R \& EMER. D/G ROOM & 5 days & Thu 20/06/19 & Wed $26 / 06 / 19$ \\
\hline & III.1.4. MATERIAL LIST & 113,75 days & Fri 05/04/19 & Wed 11/09/19 \\
\hline \multirow[t]{3}{*}{5274001} & EST. QTY. FOR STORE EXPAND METAL WALL STORE \& WORK BENCH (P/S) & 3 days & Thu 09/05/19 & Mon $13 / 05 / 19$ \\
\hline & PRODUCTION DRAWING & 202 days & Mon 22/04/19 & Tue $28 / 01 / 20$ \\
\hline & ST. WORK \& MISCELLANEOUS & 202 days & Mon 22/04/19 & Tue $28 / 01 / 20$ \\
\hline $5 Z 91101$ & FOUND OF OILY WATER SEPARATOR & 3 days & Mon 09/09/19 & Wed $11 / 09 / 19$ \\
\hline $5 Z 91015$ & FOUND. OF LO PRIMING PUMP NO.1\&2 & 3 days & Thu 12/09/19 & Mon $16 / 09 / 19$ \\
\hline $5 Z 91023$ & FOUND. OF FILTER COALESCER & 3 days & Tue $17 / 09 / 19$ & Thu $19 / 09 / 19$ \\
\hline $5 Z 91025$ & FOUND. OF ST. PANEL BILGE \& BALLAST PUMP & 2 days & Wed $22 / 01 / 20$ & Thu $23 / 01 / 20$ \\
\hline $5 Z 91005$ & FOUND. OF FRESH WATER GENERATOR NO. $1 \& 2$ & 3 days & Fri $24 / 01 / 20$ & Tue $28 / 01 / 20$ \\
\hline
\end{tabular}

\section{H. Quality Analysis of the Integrated Work Breakdown} Structure

The main strategy for optimal control is to position parts of work within a privately managed department capable of being estimated and planned. A WBS is a tool that shows the existence of a work project arranged so
Therefore the development of IWBS must be considered, including:

The regulations are used to give a sequence of levels needed to streamline work management.

TABLE 7.

\begin{tabular}{cc} 
RELATIONSHIP OUTLINE METHOD WITH WBS STRUCTURE [5] \\
\hline Level & $\begin{array}{c}\text { Method } \\
\text { Organization }\end{array}$ \\
\hline Program & Program \\
Project & Division \\
Task & Department \\
Subtask & Section \\
Work package & Individual \\
Level of effort & Individual \\
\hline
\end{tabular}

\section{Proof of Analysis}

The WBS is a tool for managing work that outlines the work towards elements of a simpler and more detailed, organized activity as well as being the basis for detailed budget estimates and time research plans. In order to improve the explanation of the WBS, the application is likened to the reference of practical procedures for reference and guidelines with the basis used so that it must obtain a high-quality WBS Project Management.

How to build an Engine Room Block like that requires a time that is at least shorter when compared to the manual method, because each shipyard builds all the Engine Room Blocks together at the same time, besides that, each shipyard has a different performance, so how to build a Machine Room Block can be short.

Based on the previous table schedule, it can be obtained that the completion of the 60 Meter Fast Attack Craft Engine Room requires:
Total Time $=$ Basic $\mathrm{MO}+$ K.P. $\mathrm{MO}+$ Y.P. $\mathrm{MO}+$ P.D. $\mathrm{MO}+$ T.P.\& T.R. M.O.

Completion of the engine room until fabrication

$=21+27+118+61+20$

$=247$ days

$=247 / 22$

$=11$ months

While examples of ships made through the Common Work Breakdown Structure require 541 days, so it can be calculated how many days the difference in completion of construction between the existing Work Breakdown Structure and the Integrated Work Breakdown Structure.

\section{J. Critical Path Method (CPM)}

The critical path is a path that has a series of activity components with the longest total amount of time and shows the fastest time to complete a project. After an analysis of dependencies between activities, the KCR 60 $\mathrm{M}$ development schedule has the following critical paths: 


\section{K. Comparison of Traditional Method \& IWBS}

$\begin{array}{ll}\text { Shipbuilding method } & \begin{array}{l}\text { Duration } \\ \text { 541 Days }\end{array} \\ \text { Without IWBS } & \text { 247 Days }\end{array}$

From the two methods used, there is a time difference:

$$
541 \text { days }-247 \text { Days }=294 \text { Days }
$$

From the two new shipbuilding methods, the following is a comparison of estimated man-hours of people between traditional methods and IWBS:
a. Total usage of MH with Traditional Method $=541 \times 8 \times 33$$$
=142.824 \text { Man Hours }
$$
b. Cost assumption (IDR 40,000 / Man Hour)
$=142.824 \times$ IDR 40.000
$=$ IDR 5.712.960.000

c. Total usage of MH with IWBS

$=247 \times 8 \times 35$

$=69.160$ Man Hours

d. Cost assumption (IDR 40,000 / Man Hour)

$=69.160 \times$ IDR 40.000

$=$ IDR 2.766.400.000

e. Man's Hours Difference

$=142.824-69.160$

= 73.664 Man Hours

f. Difference in Worker Costs

$=$ IDR 5.712.960.000 - IDR 2.766.400.000

$=$ IDR 2.946.560.000

g. Cost Difference Presentation

$=($ IDR $2.946 .560 .000 /$ IDR 5.712.960.000 $) \times 100 \%$

$=0,516 \times 100 \%$

$=51,6 \%$

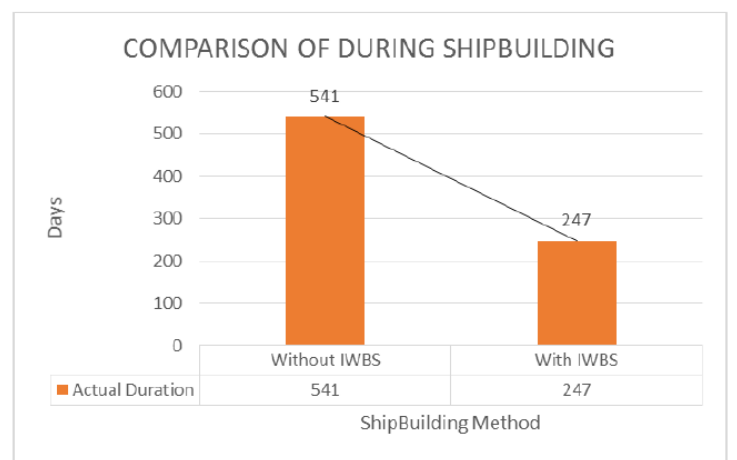

Figure. 5. Bar Chart Comparison of $60 \mathrm{M}$ Fast Attack Craft between Traditional Methods and IWBS

\section{CONCLUSION}

Based on the results of the discussion in this research, conclusions can be taken as following below:

1) There are several Work Breakdown Structure design criteria that stand out in influencing work activity planning. Where the influential factors:

- Integrating the work package structure with delivery on all factors from the initial (before the plan), plan, work, control, and final delivery.

- Group work management stage, among which: before the plan, plan, work, control, and final submission.

- Having a clear relationship design (in and out) as well as the method of the application itself.

- Supports the planning of activity processes based on responsibilities and tasks.

- Create activity job descriptions based on the development of the WBS.

- Able to create and manage activity tasks privately using the reporting organization seen on the WBS.

- Carry out making for parts of dependent activities.

2) The Integrated Work Breakdown Structure method is a method that has the aim of reducing the length of work and manufacturing in the way of building new ships.
3) The calculation of work breakdown structure is obtained by obtaining the time step of a ship's machinery equipment which takes 541 days. While the calculation of the integrated work breakdown structure method, in fact, obtained the timing of the ship's machinery outfitting was 247 days.

4) Based on the two gains, the researcher must conclude that the integrated work breakdown structure method has a shorter design time for the ship's equipment when compared to the method used in shipbuilding companies from within the State of PT. PAL before.

- Between the traditional method and IWBS, there is a difference in the duration of the work, which is 294 Days.

- Between the traditional method and IWBS there is a difference in the use of 73,664 Man Hours.

5) The use of IWBS is highly recommended because of the difference in the duration of work and the use of people's hours, it will affect the costs incurred. The difference in cost between the two methods amounts to $51.6 \%$ of the payment for worker services.

6) This process is part of the accelerated implementation of the development of a more effective design software solution application. 


\section{ACKNOWLEDGMENTS}

On this occasion, the author would like to express his gratitude to those who helped him in completing this Research. On this occasion, the author would like to express gratitude for insightful comments, criticism, and suggestion. This journal is one report series of the project "Research and builds the work breakdown structure in Shipbuilding", which is funded by Institute Technology Sepuluh November and PT. PAL Indonesia, Surabaya under-supported by the Marine Operation and Maintenance Systems Lab (MOM-LAB) under the ITSSurabaya as well also by Design Division under PAL Indonesia.

\section{REFERENCES}

[1] Office of Engineering and Construction Management \& Office of Management, Budget and Evaluation, "Work Breakdown Structure", Project Management Practices, Rev. E, Department of Energy, 2003.

[2] Smartsheet, "All About Work Breakdown Structure”, Entry from Dr. Bennet, Michelle Watkins and Rod Baxter 2019.

[3] V. T. Cang, V. N. Bich and N.A. Tuan, "3D Simulation-based Support Systems in PLM Solution for Offshore and Marine Industry", Marine Engineering Frontiers (MEF), Volume 1, Issue 4, Ho Chi Minh City, pp. 82-89, 2013.

[4] M. Faridy, "Analisis Simulasi Konsep Pembangunan Kapal Multi Galangan pada PT DKB untuk Pembangunan Kapal Tanker 6200 DWT", Skripsi S.T., U.I., Depok, 2010.

[5] Project Management Institute, "Project Management Institute Practice Standard for Work Breakdown Structures, $2^{\text {nd }}$ Edition", ISBN 1-933890-13-4, 2006.

[6] Firdiyanto, Ilham, Muqtadiroh, F.A. and Herdiyanti, A., "Pembuatan Work Breakdown Structure dalam rangka Implementasi MOOC ITS menggunakan EMMA Framework", Seminar Nasional Sistem Informasi Indonesia, Surabaya, on page 97-106, 2018

[7] G. D. Wijaya, F. Marsiano and S. Limanto, "Studi Kasus Penjadwalan Proyek pada Rumah Toko X menggunakan Microsoft Project 2010", University Kristen Petra, 2010.

[8] G. S. Peace, "Taguchi Methods a Hands on Approach", New York Addison - Wesley Publishing, 1993.

[9] Government Industry Workshop, "Expanded Work Breakdown Structure Weight Classification Guidance", Revision 2, International Society of Allied Weight Engineers, Inc., Los Angeles, 2011.

[10] Groover, M.P., “Automation Production Systems and Computer Integrated Manufacturing", Prentice-Hall, 1987.

[11] J. L. Burbidge, "The Introduction of Group Technology", William Heineman, London, 1975.

[12] J. Lee et al, "Integrating Process and Work Breakdown Structure with Design Structure Matrix", Journal of Advanced Computational Intelligence and Intelligent Informatics, Vol. 14 No. 5, pp. 512-522, 2010.

[13] L. K. Chan and P. H. Xiao, "Combined Robust Design", Manitoba: Marcel Dekker and ASQC, 1995.
[14] L. S. R. Supriadi, Y. Latief, B. Susilo and M. Rajasa, "Development of Risk-Based Standardized WBS (Work Breakdown Structure) for Cost Estimation of Apartment's Project", International Journal of Civil Engineering and Technology, 8(10), pp. 822-833, 2017.

[15] Lamb, Thomas, "Engineering for Ship Production", The Society of Naval Architects and Marine Engineers, 1986.

[16] Department of Commerce, "Product Work Breakdown Structure", Maritime Administration, U.S., San Francisco, California, 1980.

[17] M. Pal, "Ship Work Breakdown Structures through different Ship Lifecycle Stages", International Conference on Computer Application in Shipbuilding, The Royal Institute of Naval Architects, Bremen, Germany, 2015.

[18] M. Z. Solesvik, "Collaborative knowledge management: case studies from ship design", Int. J. Business Information Systems, Vol. 8, No. 2, pp. 131-145, 2011.

[19] A. H. Jebrin, "Integrating Work Breakdown Structure with the Organization Breakdown Structure (Approach Theoretical", International Journal of Science and Research Methodology, Human Journal, Vol.: 11 (1): 125-142, 2018.

[20] Djaya, Indra Kusna, et al., "Teknik Konstruksi Kapal Baja Jilid 2 SMK", Direktorat Pembinaan SMK, 2008.

[21] R. A. Shenoi, "Ship Production Technology", Ship Science Report No.37, University of Southampton, 1989.

[22] Roswidiyastuti, Windi, "Kriteria Work Breakdown Structure untuk Pengendalian Proyek yang Efektif", Skripsi, Fakultas Teknik, Program Studi Teknik Sipil, Depok, 2009.

[23] Rubesa, Rajko, Fafandjel, Niksa \& Kolic Damir, "Procedure for Estimating the Effectiveness of Ship Modular Outfitting”, Eng. Rev., Faculty of Engineering, University of Rijeka, Rijeka, hal. 55-62, 2011.

[24] Saraswati, Rahaju, Azhar, Ali et al., "Perancangan Group Technology Layout di PT DPS Surabaya dengan Metode Simulasi dan Taguchi”, Jurnal Teknik Industri, Vol. 12, No. 2, Universitas WR. Supratman, Sby, hal. 104-109, 2011.

[25] C. R. Griyantia, I. P. Mulyatno and Kiryatno, "Studi Rancang Reschedule Pembangunan Kapal Baru menggunakan Full Outfitting Block System (FOBS) dengan Project CPM pada Kapal LCT 200 GT”, Jurnal Teknnik Perkapalan, Vol. 3, No. 4, hal. 546-556, 2015.

[26] Solesvik, Marina, Z., "A Collaborative Design in Shipbuilding: Two Case Studies", 1-4244-0865-2 IEEE, Maritime Research Program, Stord University College, Haugesund, 299-304, 2007.

[27] Sunaryo, "Multi-Yard Ship Construction and Productivity", Stracthcycle University, 1993.

[28] Suwarsono, Bagiyo, "Manajemen Produksi Kapal". Direktorat Jenderal Pendidikan Tinggi, 2004.

[29] T. Rando, "A State of the Art Report of CAD/CAM/CIM Systems Technologies for the U.S. Shipbuilding Industry", Electric Boat Corporation, May, 2002.

[30] D. J. Eyres, "Ship Production", Butterworth Heinemann, Oxford, U.K., 2001

[31] W.A.Z. Wan Abd Rahman, N.I. Mohd Zaki and M.K. Abu Husain, "A Review of Work Breakdown Structure and ManHours Estimation Method used in Shipbuilding Production", International Journal of Mechanical Engineering and Technology, 10(01), page. 1141-1158, 2019.

[32] Y. Okayama and L.D. Chirilo, "Product Work Breakdown Structure", National Shipbuilding Research Program, in cooperation with Todd Pacific Shipyards Corporation, 1982. 